\title{
PEMBADANAN HUKUM FINTECH SEBAGAI INSTRUMEN PENGATURAN PERSAINGAN USAHA YANG SEHAT ${ }^{1}$
}

\author{
Otih Handayani $^{1 *}$ dan Adi Sulistiyono ${ }^{2}$ \\ ${ }^{1}$ Fakultas Hukum Universitas Bhayangkara Jakarta Raya \\ Jl. Harsono RM No 67, Ragunan, Pasar Minggu, Jakarta Selatan \\ ${ }^{2}$ Fakultas Hukum Universitas Sebelas Maret \\ J1. Ir. Sutami 36.A Surakarta, 57126 \\ otih.handayani@gmail.com
}

\begin{abstract}
Financial Technology (Fintech), a new paradigm of financial services, developing very fast to penetrate the world without barriers. This study aims to embodying Fintech Law as an instrument for regulating fair business competition. This research is a normative legal research, data collected by literature study, analyzed qualitatively. The results of the study describe the phenomenon of the Fintech Association which has 78\% members set a loan interest of 0.8 percent per day which results in consumers having less choice when using Fintech. Weak legal instruments have resulted in unfair business competition, one of which is in the form of a cartel. Embodying Fintech Law will be able to eliminate the Fintech cartel and provide legal protection for consumers to receive fair treatment.
\end{abstract}

Keywords: Embodying; Cartel; Financial Technology (Fintech)

\begin{abstract}
Abstrak
Revolusi Industri 4.0. melahirkan Financial Technology (Fintech) sebagai paradigma baru di bidang jasa keuangan merupakan akselerasi pemberian pinjaman dana dengan memanfaatkan proses otomatis dan menyederhanakan proses pinjaman. Penelitian ini bertujuan untuk membadankan Hukum Fintech sebagai instrumen pengaturan persaingan usaha yang sehat. Penelitian ini adalah penelitian hukum doktrinal/normatif dengan pendekatan perundangundangan. Data dikumpulkan dengan studi kepustakaan, dianalisis secara kualitatif. Hasil Penelitian mendeskripsikan fenomena Asosiasi Fintech yang beranggotakan 78\% menetapkan bunga pinjaman 0,8 persen per hari yang mengakibatkan konsumen kurang memiliki pilihan apabila menggunakan Fintech. Lemahnya instrumen hukum berdampak pada terjadinya persaingan usaha yang tidak sehat yang salah satunya berbentuk kartel. Pembadanan hukum Fintech akan mampu meniadakan kartel Fintech dan memberikan perlindungan hukum bagi konsumen mendapatkan perlakuan yang fair sehingga dapat mendorong pertumbuhan ekonomi dan bekerjanya ekonomi pasar yang wajar.
\end{abstract}

Kata Kunci: Pembadanan; Kartel; Financial Technology (Fintech)

\footnotetext{
${ }^{1}$ Merupakan artikel hasil penelitian mandiri dalam kajian hukum persaingan usaha (business law). 


\section{A. Pendahuluan}

Saat ini dunia mengalami Revolusi Industri 4.0 atau Era Disrupsi 4.0, suatu keadaan dimana perpaduan teknologi mengaburkan batas antara bidang fisik, digital, biologis atau secara kolektif disebut sebagai sistem siber fisik (cyber physical system/cps). Revolusi Industri 4.0 meliputi berbagai industri di antaranya transportasi, penjualan retail, keuangan, agrikultur, asuransi, kesehatan dan lain-lain.

Di sektor jasa, inovasi berbasis teknologi di antaranya di bidang keuangan atau Financial Technology (Fintech) telah merambah ke berbagai sektor, seperti startup pembayaran, peminjaman (lending), perencanaan keuangan (personal finance), investasi ritel, pembiayaan (crowdfunding), uang elektronik, dan lain-lain diharapkan dapat membangun ekonomi inklusif. Pada Fintech, $P 2 P$ Lending adalah komponen terbesar, secara global bisnis ini dapat dilihat pada Republik Rakyat Tiongkok (RRC) dan AS sebagai pasar terbesar di dunia, dengan $\$$ 100 miliar kredit Fintech baru yang dikeluarkan di RRC pada 2015 dan \$ 34 miliar di AS. Pinjaman kepada perorangan terdiri dari sebagian besar $P 2 P$ Lending di RRC dan AS. P2P Lending untuk bisnis masih relatif kecil tetapi telah berkembang pesat (Nemoto et al., 2019). Di Indonesia per Januari 2020, jumlah dana kredit yang telah disalurkan mencapai $\mathrm{Rp} 88.3$ triliun (OJK, n.d.-a).

Sampai dengan saat ini industri Fintech masih diatur oleh Peraturan OJK (POJK) Nomor 77 Tahun 2016 tentang Layanan Pinjam Meminjam Uang Berbasis Teknologi Informasi (Santi et al., 2017). Tanpa didukung oleh landasan hukum yang jelas seringkali Fintech disalahgunakan oleh pihak-pihak yang terlibat di dalamnya.

Di penghujung tahun 2019, Polres Metro Jakarta Utara melakukan tindakan penegakan hukum kepada PT. Barracuda Fintech Indonesia. Dua warga negara asal China yang diduga otak dari pinjaman online ilegal (Fintech) yaitu Feng Qian alias OL sebagai Direktur Utama dan Dian Xiao Liang alias TD sebagai wakil direktur diduga melakukan ancaman dan pemerasan melalui Penagih Utang (debt collector) kepada nasabah (Liputan6, n.d.). Kasus ini sesungguhnya hanya satu dari sekian banyak kasus yang menimpa warga masyarakat menengah ke bawah akibat maraknya bisnis Fintech. Hingga akhir 2019, Satuan Tugas Penanganan Dugaan Tindakan Melawan Hukum di Bidang Penghimpunan Dana Masyarakat dan Pengelolaan Investasi dibentuk berdasarkan Keputusan Dewan Komisioner Otoritas Jasa Keuangan Nomor: 01/KDK.01/2016 tanggal 1 Januari 2016 (OJK, n.d.-b), Satgas Waspada Investas) telah menindak 1.898 entitas P2P Lending illegal (Kontan.co.id, n.d.). Hal lain adalah potensi terjadinya praktek kartel pada $P 2 P$ Lending melalui Asosiasi yang menetapkan bunga pinjaman pada anggota Asosiasi.

Akibat lain dari belum jelasnya instrumen pengatur Fintech yaitu dugaan pelanggaran terhadap Undang-Undang Republik Indonesia Nomor 5 Tahun 1999 Tentang Larangan Praktek Monopoli Dan Persaingan Usaha Tidak Sehat di antaranya pasal 11 tentang Kartel yang berbunyi: "Pelaku usaha dilarang membuat perjanjian, dengan pelaku usaha pesaingnya, yang bermaksud untuk mempengaruhi harga dengan mengatur produksi dan atau pemasaran suatu barang atau jasa, yang dapat mengakibatkan terjadinya praktek monopoli dan atau persaingan usaha tidak sehat".

Dengan jumlah penduduk sekitar 270.000.000 (dua ratus tujuh puluh juta) jiwa, saat ini pengguna internet di Indonesia, jumlahnya mencapai 171 juta. Potensi pasar online yang sangat besar di Indonesia sudah pasti berpotensi pada terjadi persaingan usaha tidak hanya bagi para pelaku bisnis dalam negeri melainkan juga menjadi target raksasa-raksasa bisnis internasional. Di antara pelaku usaha pada bidang sejenis terjadi persaingan usaha yang semakin tajam. Kondisi demikian menuntut perusahaan untuk secara cepat dan tepat mencari strategi agar dapat terus mempertahankan eksistensinya namun, banyak di antara pengusaha-pengusaha tersebut seringkali 
menggunakan jalan pintas dalam menerapkan strategi yang digunakan dengan menggunakan persengkongkolan dalam bentuk suatu perjanjian yang memuat ketentuan yang dapat mengakibatkan terjadinya praktek kartel dan persaingan usaha tidak sehat (Barita \& Sulistiyono, 2019). Oleh karenanya dibutuhkan pembadanan hukum Fintech untuk menyelamatkan berbagai pihak yang dapat mengakomodir tidak terbendungnya model bisnis baru yang memanfaatkan kemajuan teknologi.

State of the art penelitian ini diambil dari beberapa contoh penelitian terdahulu dalam bentuk jurnal di antaranya penelitian berjudul Kekosongan Norma Penentuan Bunga Pinjaman Financial Technology Peer To Peer Lending oleh Antoni Tjandra membahas tentang perlindungan hukum pada debitur terhadap suku bunga pinjaman peer to peer lending 0,8\% per hari (batas maksimum) dikeluarkan oleh Asosiasi Fintech Pendanaan Bersama Indonesia (AFPI), penelitian berjudul Legalitas Penggunaan Metode Harrington Dalam Praktik Kartel (Studi Kasus Praktik Kartel Ban Kendaraan Roda Empat) oleh Hendrik Barita dan Adi Sulistiyono, membahas tentang KPPU membutuhkan bukti tidak langsung untuk membuktikan adanya perjanjian kartel di antara pelaku usaha dan penelitian berjudul Pengawasan Otoritas Jasa Keuangan Terhadap Financial Technology Peraturan Otoritas Jasa Keuangan Nomor 77/POJK.01/2016) oleh Ernama Santi, Budiharto, Hendro Saptono membahas hubungan hukum para pihak yang terlibat dalam fintech dan mengetahui pelaksanaan pengawasan yang dilakukan oleh ojk terhadap fintech. Kebaruan dari penelitian kami adalah membahas hubungan ketiga penelitian tersebut di atas yang menghasilkan suatu kesimpulan bahwa diperlukan pembadanan (embodying) prinsip-prinsip, norma, dan aturan hukum fintech guna memayungi kepentingan pelaku usaha, mitra usaha, pesaing, dan pengguna jasa guna mencegah dan menindak praktek mononopoli dan persaingan usaha tidak sehat.

Teori hukum atau asas hukum yang menjadi kerangka teoritis dalam penelitian ini adalah Teori Keadilan yang digawangi oleh Jhon Rawls yang menyatakan bahwa prinsip keadilan sosial merupakan dasar untuk menetapkan distribusi prospek untuk mendapatkan barang-barang pokok. Kebutuhan dasar meliputi hak-hak dasar, kebebasan, kekuasaan, kewibawaan, kesempatan, pendapatan dan kesejahteraan.

Tulisan ini memfokuskan pada beberapa permasalahan yaitu: (1) Bagaimana UndangUndang Nomor 5 tahun 1999 tentang larangan praktek monopoli dan persaingan usaha tidak sehat memayungi kepentingan pelaku usaha, mitra usaha, pesaing, dan pengguna jasa pada bisnis Financial Technology Era Revolusi 4.0.?, dan; (2) Bagaimana pembadanan hukum fintech dapat menjadi instrumen pengaturan persaingan usaha yang sehat?

\section{B. Metode Penelitian}

Metode yang digunakan dalam penelitian ini adalah penelitian yuridisnormatif. Penelitian normatif atau kepustakaan merupakan penelitian hukum yang dilakukan dengan cara meneliti bahan pustaka atau data sekunder. Dalam penelitian ini menggunakan Undang-Undang Republik Indonesia Nomor 5 Tahun 1999 Tentang Larangan Praktek Monopoli dan Persaingan Usaha Tidak Sehat; Peraturan Otoritas Jasa Keuangan Nomor: 77/KDK.01/2016 tentang Layanan Pinjam Meminjam Uang Berbasis Teknologi Informasi. Data sekunder yang digunakan dalam penelitian ini adalah data sekunder berupa buku-buku, peraturan-peraturan, karya ilmiah dan kamus hukum. Metode analisis data yang digunakan dalam penelitian ini adalah metode kualitatif. 


\section{Hasil Penelitian dan Pembahasan}

1. Pengaturan Undang-Undang Nomor 5 Tahun 1999 terhadap Kepentingan Pelaku Usaha, Mitra Usaha, Pesaing, dan Pengguna Jasa pada Bisnis Financial Technology Era Revolusi 4.0

Pengertian Fintech menurut Committee on the Global Financial System, Financial Stability Board "technologically enabled financial innovation that could result in new business models, applications, processes, or products with an as- sociated material effect on financial markets and institutions and the provision of financial services" (Omarini, 2018).

Peraturan Otoritas Jasa Keuangan (POJK) No. 77 tahun 2016 menjelaskan bahwa $P 2 P$ lending merupakan penyelenggaraan layanan jasa keuangan untuk mempertemukan pemberi pinjaman dengan penerima pinjaman dalam rangka melakukan perjanjian pinjam meminjam dalam mata uang rupiah secara langsung melalui sistem elektronik dengan menggunakan jaringan internet (Darman, 2019). Proses pengajuan $P 2 P$ Lending sangatlah mudah dan sederhana, calon debitur hanya memerlukan KTP, rekening bank, kartu tanda karyawan, dan kontak keluarga atau teman dekat. Berbeda dengan pinjaman di bank yang seringkali harus melewati beberapa tahapan, mulai dari pengajuan, wawancara, hingga survei.

\section{a. Persaingan Usaha pada Fintech Peer to Peer Lending (P2P Lending)}

Menurut Adam Smith dalam The Wealth of Nations (1776), persaingan akan mendorong alokasi faktor produksi ke arah penggunaan yang paling bernilai tinggi dan efisien (Economics \& Edition, 2008). Adanya persaingan menyebabkan perusahaan-perusahaan komersial mengembangkan produk, teknologi dan jasa, sehingga menyebabkan lebih banyaknya pilihan, menghasilkan produk yang lebih baik, dan harga yang lebih rendah.

Hukum persaingan usaha penting dalam ekonomi pasar sebagai upaya pemerintah melindungi persaingan yang sehat antar pelaku usaha di dalam pasar. Pasal 1 angka 6 UU No.5 Tahun 1999 menyatakan bahwa Persaingan usaha tidak sehat adalah persaingan antar pelaku usaha dalam menjalankan kegiatan produksi dan atau pemasaran barang atau jasa yang dilakukan dengan cara tidak jujur atau melawan hukum atau menghambat persaingan usaha. Hal lain yaitu pasal 2 menyatakan "Pelaku usaha di Indonesia dalam menjalankan kegiatan usahanya berasaskan demokrasi ekonomi dengan memperhatikan keseimbangan antara kepentingan pelaku usaha dan kepentingan umum".

Secara umum, materi dari UU No.5 Tahun 1999 ini mengandung 6 (enam) bagian pengaturan yang terdiri dari: perjanjian yang dilarang; kegiatan yang dilarang; posisi dominan; Komisi Pengawas Persaingan Usaha; penegakan hukum; ketentuan lain-lain.

\section{b. Perjanjian yang Dilarang (Kartel)}

Salah satu bentuk perjanjian yang dilarang menurut undang-undang ini adalah Kartel. Istilah kartel berasal dari bahasa Latin, yaitu cartellus, dalam Black's Law Dictionary, kartel didefinisikan sebagai, "A combination of producers or sellers that join together to control a product's production or price. An association of firms with common interest, seeking to prevent extreme on unfair competition, allocate markets, or share knowledge" (Garner, 2004). Menurut Lee McGowan, "cartels are a combination to divide up markets and fix prices (generally higher to maximise profit) among themselves (Baruchello, 2013). Sedangkan Richard A. Posner menjelaskan bahwa kartel adalah, " $A$ contract among competing sellers to fix 
the price of the product they sell (or, what is the same thing, to limit their output) is like any other contract in the sense that the parties would not sign it unless they expected it to make them all better off (Posner, 2012).

Membanjirnya pasokan dari suatu produk tertentu di dalam suatu pasar, dapat membuat harga dari produk tersebut di pasar menjadi lebih murah, kondisi ini akan menguntungkan bagi konsumen, tetapi tidak bagi pelaku usaha (produsen atau penjual). Agar harga pokok di pasar tidak jatuh dan harga produk dapat memberikan keuntungan yang sebesar-besarnya bagi pelaku usaha, pelaku usaha biasanya membuat perjanjian di antara mereka untuk mengatur mengenai jumlah produksi sehingga jumlah produksi merekea di pasar tidak berlebih, dan tujuannya agar tidak membuat harga produk mereka di pasar menjadi lebih murah. Seringkali praktek kartel juga untuk mengeruk keuntungan yang sebesar-besarnya dengan mengurangi produk mereka secara signifikan di pasar, sehingga menyebabkan di dalam pasar mengalami kelangkaan, yang mengakibatkan konsumen harus mengeluarkan biaya yang lebih untuk dapat membeli produk pelaku usaha tersebut di dalam pasar atau dapat dikatakan tujuan utama dari praktek kartel adalah untuk mengeruk sebanyak mungkin surplus konsumen ke produsen. Oleh karena Kartel menukar kompetisi dengan tindakan-tindakan yang kolutif diantara pesaing, maka dilarang dalam hukum persaingan usaha (Andersen \& Rogers, 1999).

Karakteristik dari perjanjian kartel yaitu: pertama, perjanjian termasuk juga tindakan bersama (concerted action) yang dilakukan secara tertulis maupun tidak tertulis, dan bersifat sukarela; kedua, dilakukan oleh para pelaku usaha yang bersifat persaingan (bersifat horizontal) maupun pelaku usaha lainnya yang bersifat independen (bersifat vertikal); dan ketiga, bertujuan untuk mencegah, membatasi, ataupun mendistorsi persaingan di antara mereka (Antoni, 2019).

Selain karakteristik tersebut ada pula pendapat lain menyatakan bahwa suatu kartel pada umumnya mempunyai beberapa karakteristik (Bhakti, 2015): 1) Terdapat konspirasi di antara beberapa pelaku usaha; 2) Melibatkan para senior eksekutif dari perusahaan yang terlibat. Para senior eksekutif inilah biasanya yang menghadiri pertemuan-pertemuan dan membuat keputusan; 3) Biasanya dengan menggunakan asosiasi untuk menutupi kegiatan mereka.

Setidaknya ada tiga cara melakukan kartel, yaitu melalui harga, produksi dan wilayah pemasaran. Hal ini mengakibatkan terjadinya kerugian berupa terjadinya praktek monopoli oleh para pelaku kartel, sementara itu bagi konsumen kehilangan pilihan harga, kualitas yang bersaing dan layanan purna jual yang baik (Nasution \& Winarti, 2008). Oleh karenanya Undang-Undang Republik Indonesia Nomor 5 Tahun 1999 Tentang Larangan Praktek Monopoli Dan Persaingan Usaha Tidak Sehat melarang hal tersebut sebagaimana tercantum dalam pasal Pasal 5 ayat (1) yang berbunyi: Pelaku usaha dilarang membuat perjanjian dengan pelaku usaha pesaingnya untuk menetapkan harga atas suatu barang dan atau jasa yang harus dibayar oleh konsumen atau pelanggan pada pasar bersangkutan yang sama (UU Nomor 5 Tahun 1999 Tentang Larangan Praktek Monopoli Dan Persaingan Usaha Tidak Sehat, 1999).

\section{c. Potensi Kartel pada Peer To Peer Lending}

Hingga Maret 2020, Asosiasi Fintech Pendanaan Bersama Indonesia (AFPI) beranggotakan 128 dari 164 penyelenggara $P 2 P$ Lending yang sudah 
terdaftar dan berizin di OJK (menguasai $78 \%$ ). Dengan penguasaan sebesar ini maka menurut Pasal 4 ayat (2) UndangUndang Republik Indonesia No. 5 Tahun 1999 Tentang Larangan Praktek Monopoli Dan Persaingan Usaha Tidak Sehat dikategorikan sebagai oligopoli yaitu: Pelaku usaha patut diduga atau dianggap secara bersama-sama melakukan penguasaan produksi dan atau pemasaran barang dan atau jasa, sebagaimana dimaksud ayat (1), apabila 2 (dua) atau 3 (tiga) pelaku usaha atau kelompok pelaku usaha menguasai lebih dari 75\% (tujuh puluh lima persen) pangsa pasar satu jenis barang atau jasa tertentu.

Di dalam teori ekonomi mikro, model oligopoli dibagi dalam 2 (dua) jenis, yaitu (Koutsoyiannis, n.d.): 1) Oligopoli non-kolusif, dimana setiap tindakan yang dilakukan oleh suatu produsen akan memancing reaksi dari produsen lain; 2) Oligopoli kolusif, terdiri dari kartel dan penentuan harga, dimana kerjasama sejumlah perusahaan yang bersaing untuk mengkoordinasi kegiatannya sehingga dapat mengendalikan jumlah produksi dan harga suatu barang dan/atau jasa untuk memperoleh keuntungan diatas tingkat keuntungan yang wajar.

Pada struktur pasar persaingan sempurna, jumlah pelaku usaha banyak dan tidak ada hambatan bagi pelaku usaha untuk masuk ke dalam pasar, akibatnya setiap pelaku usaha dalam pasar tersebut tidak dapat mengendalikan harga. Sebaliknya dalam pasar oligopoli potensi kerjasama para pelaku usaha untuk menentukan harga produk dan jumlah produksi masingmasing pelaku usaha menjadi besar, hal ini menjadi lahan subur terjadinya kartel dimana pelaku usaha bersatu untuk menguasai sebagian besar pangsa pasar (Hovenkamp, 2016).

Salah satu sumber pendapatan jasa keuangan bersumber dari pendapatan bunga. Suku bunga adalah persentase tertentu yang diperhitungkan dari pokok pinjaman yang harus dibayarkan oleh debitur dalam periode tertentu, dan diterima oleh kreditur sebagai imbal jasa. Imbal jasa ini merupakan suatu kompensasi kepada pemberi pinjaman (kreditur) karena telah merelakan debitur (peminjam dana) untuk mendapatkan manfaat dari dana yang dimilikinya, alih-alih menggunakannya untuk tujuan lain (Nuraini, 1999).

\section{d. Penetapan Suku Bunga Perbankan}

Bunga bank adalah tambahan yang disebabkan karena adanya simpanan maupun pinjaman antara pihak nasabah dan pihak bank dari pokok simpanan dan pokok pinjaman yang dilakukan atau ditransaksikan (Romdhoni et al., 2012). Menurut Erawati dan Llewelyin (2002), suku bunga juga merupakan salah satu faktor yang penting dalam perekonomian suatu negara karena sangat berpengaruh terhadap "kesehatan" suatu perekonomian.

Bank Indonesia sebagai regulator melalui Undang-Undang Republik Indonesia No. 23 Tahun 1998 tentang Bank Indonesia menetapkan suku bunga kebijakan Bank Indonesia (Bank Indonesia Rate - BI Rate) sebagai kebijakan nilai suku bunga terkait dengan kebijakan moneter yang akan diterapkan pada masyarakat seluruh Indonesia.

BI Rate ditetapkan setiap bulan melalui rapat anggota Dewan Gubernur dengan mempertimbangkan kondisi perekonomian baik di Indonesia maupun situasi perekonomian global secara umum yang kemudian menjadi kebijakan moneter untuk penentuan suku bunga yang dipakai sebagai acuan bank-bank yang lainnya di Indonesia. Fungsi dari BI Rate agar diimplementasikan pada operasi moneter yang dilakukan Bank Indonesia melalui pengelolaan likuiditas (liquidity management) di pasar uang untuk 
mencapai sasaran operasional kebijakan moneter (Romdhoni et al., 2012).

Pada tanggal 19 Agustus 2016 Bank Indonesia (BI) mengumumkan formula baru suku bunga acuan perbankan, yakni BI 7-Day Reverse Repo Rate (BI-7-DRRR), yang menggantikan formula sebelumnya yakni BI Rate. Dengan penggunaan instrumen BI-7-DRRR sebagai suku bunga kebijakan baru, terdapat tiga dampak utama yang diharapkan. Pertama, menguatnya sinyal kebijakan moneter dengan suku bunga (Reverse) Repo Rate 7 hari sebagai acuan utama di pasar keuangan. Kedua, meningkatnya efektivitas transmisi kebijakan moneter melalui pengaruhnya pada pergerakan suku bunga pasar uang dan suku bunga perbankan. Ketiga, terbentuknya pasar keuangan yang lebih dalam, khususnya transaksi dan pembentukan struktur suku bunga di pasar uang antarbank (PUAB) untuk tenor 3-12 bulan (Bank Indonesia, n.d.).

Pasal 51 Undang-Undang Republik Indonesia Nomor 5 Tahun 1999 Tentang Larangan Praktek Monopoli Dan Persaingan Usaha Tidak Sehat, menyatakan: Monopoli dan atau pemusatan kegiatan yang berkaitan dengan produksi dan atau pemasaran barang dan atau jasa yang menguasai hajat hidup orang banyak serta cabangcabang produksi yang penting bagi negara diatur dengan undang-undang dan diselenggarakan oleh Badan Usaha Milik Negara dan atau badan atau lembaga yang dibentuk atau ditunjuk oleh Pemerintah. Berdasarkan pasal ini maka menetapan BI-7DRRR yang mendasarkan pada Undang-Undang Republik Indonesia No. 23 Tahun 1998 tentang Bank Indonesia dapat dikecualikan dari Undang-Undang Republik Indonesia Nomor 5 Tahun 1999 Tentang Larangan Praktek Monopoli Dan Persaingan Usaha Tidak Sehat, sehingga tidak dapat dikategorikan sebagai Kartel (monopoly by law).

\section{e. Penetapan Suku Bunga P2P Lending}

Para pelaku $P 2 P$ Lending tergabung dalam Asosiasi Fintech Pendanaan Bersama Indonesia (AFPI). AFPI ditunjuk Otoritas Jasa Keuangan (OJK) sebagai asosiasi resmi penyelenggara layanan pinjam meminjam uang berbasis teknologi informasi di Indonesia, berdasarkan surat No. S-5/D.05/2019 (AFPI, n.d.). AFPI membantu OJK dalam mengatasi banyaknya penyelenggara Fintech ilegal yang membuka layanan jasa keuangan Peer to Peer Lending (Tjandra, 2020). AFPI menetapkan bunga pinjaman 0,8 persen per hari. Asosiasi melihat besaran bunga di negara Inggris yang menjadi patokan dimana bunga pinjaman supreme-nya sebesar $0,8 \%$ (CnbcIndonesia, n.d.).

Berdasarkan Karakteristik dari perjanjian kartel maka sesungguhnya penetepan bunga $P 2 P$ Lending oleh AFPI memenuhi unsur-unsur kartel yaitu: Pertama, adanya tindakan bersama (concerted action) sepakat dengan bunga pinjaman sebesar 0,8 persen per hari; dengan jumlah anggota yang meliputi $78 \%$ P2P Lending termasuk dalam oligopoli kolutif dimana kerjasama sejumlah perusahaan yang bersaing untuk mengkoordinasi kegiatannya sehingga dapat mengendalikan jumlah tingkat suku bunga untuk memperoleh keuntungan di atas tingkat keuntungan yang wajar. Kedua, dilakukan oleh para pelaku usaha melalui Asosiasi yang terdiri dari perusahaan-perusahaan $P 2 P$ Lending yang sesungguhnya ada pesaingan di antara mereka; asosiasi menjadi sarana untuk menutupi kegiatan kartel suku bunga $P 2 P$ Lending. Ketiga, bertujuan untuk mencegah, membatasi, ataupun mendistorsi persaingan di antara para pelaku usaha $P 2 P$ Lending. Dengan 
menetapkan bunga pinjaman 0,8 persen per hari anggota Asosiasi menjadikan nilai tersebut sebagai acuan dalam menjalankan kegiatannya.

Penetapan bunga pinjaman oleh Asosiasi dan bukan Regulator sesungguhnya tidak memiliki dasar hukum yang kuat, dibandingkan dengan penetapan suku bunga acuan BI-7DRRR yang ditetapkan oleh Bank Indonesia. Menurut Mantan Ketua Komisi Pengawas Persaingan Usaha (KPPU) sekaligus Pendiri Institute for Competition and Policy Analysis (ICPA), Syarkawi Rauf jika penentuan besaran bunga dilakukan melalui regulator, maka hal itu tidak jadi kewenangan KPPU. KPPU tidak bisa melakukan penyelidikan akan hal itu karena ketika kebijakan yang dibuat melalui regulator masuk poin pengecualian objek penyelidikan KPPU (CnbcIndonesia, n.d.).

Dalam hal suku bunga pinjaman Fintech $P 2 P$ Lending sesungguhnya belum ada pihak yang memiliki kewenangan termasuk juga OJK meski hingga saat ini OJK merupakan Regulator dari Fintech $P 2 P$ Lending oleh karenanya penetapan bunga pinjaman 0,8 persen per hari oleh AFPI untuk $P 2 P$ Lending tidak dapat dikategorikan sebagai Monopoly by Law (sebagaimana penetapan BI-7DRRR oleh BI) dan patut untuk dimasukkan dalam "Perjanjian Yang Dilarang (Kartel)".

\section{Pembadanan Hukum Fintech sebagai Instrumen Persaingan Usaha yang Sehat}

Dalam konteks kegiatan ekonomi, pembadanan (embodying) prinsip-prinsip, norma, dan aturan hukum fintech merupakan pengembanan hukum yang signifikan. Istilah pengembanan hukum berasal dari istilah yang digunakan oleh Meuwissen yaitu 'rechtsbeoefening', yaitu kegiatan manusia berkenaan dengan adanya dan berlakunya hukum di dalam masyarakat. Kegiatan tersebut mencakup kegiatan membentuk, melaksanakan, menerapkan, menemukan, meneliti, dan secara sistematikal mempelajari dan mengajarkan hukum yang berlaku itu (Shidarta, 2018).

Jhon Rawls menyatakan bahwa prinsip keadilan sosial merupakan merupakan dasar untuk menetapkan ditribusi prospek untuk mendapatkan barang-barang pokok. Kebutuhan dasar meliputi hak-hak dasar, kebebasan, kekuasaan, kewibawaan, kesempatan, pendapatan dan kesejahteraan. Prinsip-prinsip keadilan harus mengerjakan dua hal pertama Prinsip keadilan harus memberi penilaian kongkret tentang adil tidaknya institusi-institusi dan praktek institusional. Kedua Prinsip-prinsip keadilan harus membimbing kita dalam memperkembangkan kebijakan-kebijakan dan hukum untuk mengoreksi ketidakadilan dalam struktur dasar masyarakat tertentu (Rawls, 2019). Sedikitnya terdapat tiga pihak yang terkait dalam Fintech yaitu pemberi dana, penyelenggara dan penerima dana, ketiganya hendaknya mendapatkan keadilan sama yang dituangkan dalam aturan yang komprehensif.

Pembadanan hukum Fintech yang adil dapat menjadi instrument persaingan usaha yang sehat, maka prinsip, norma, dan aturan terkait Larangan Praktek Monopoli dan Persaingan Usaha Tidak Sehat harus menjadi fokus perhatian, di antaranya pengaturan tentang: definisi pelaku usaha, pasar yang bersangkutan, dan pengaturan tentang ekstrateritorialitas.

\section{a Pelaku Usaha}

Berdasarkan ketentuan Pasal 1 angka 5 UU Nomor 5 Tahun 999 dinyatakan bahwa yang dimaksud dengan pelaku usaha adalah: "setiap orang perorangan atau badan usaha, baik yang berbentuk badan hukum yang didirikan dan berkedudukan atau melakukan kegiatan dalam wilayah hukum negara Republik Indonesia, baik sendiri maupun bersama-sama melalui perjanjian, menyelenggarakan berbagai kegiatan usaha dalam bidang ekonomi". 
Dalam hukum perdata diakui bahwa suatu badan hukum (sebagai suatu subyek hukum mandiri; persona standi in judicio) dapat melakukan perbuatan melawan hukum (onrechtmatig handelen; tort). Badan hukum mempunyai kewenangan melakukan perbuatan hukum seperti halnya orang, akan tetapi perbuatan hukum itu hanya terbatas pada bidang hukum harta kekayaan. Mengingat wujudnya adalah badan atau lembaga, maka dalam mekanisme pelaksanaannya badan hukum bertindak dengan perantara pengurus-pengurusnya. Untuk Asosiasi yang dikategorikan sebagai perkumpulan, diatur dalam Pasal 1653 KUHPerdata.

\section{b. Pasar yang Bersangkutan}

Penentuan pasar bersangkutan secara tepat diperlukan untuk mengukur struktur pasar dan batasan dari perilaku anti-persaingan yang dilakukan, sehingga dapat mengidentifikasi pesaing nyata dari pelaku usaha dominan dan dapat membatasi perilakunya. Pendefinisian pasar bersangkutan yang terlalu sempit dapat membawa kepada hal-hal yang tidak berhubungan dengan persaingan, dan sebaliknya definisi pasar bersangkutan yang terlalu lebar dapat menyamarkan permasalahan yang sebenarnya. Ini tentu saja menjadi suatu kasus dimana penekanan terlalu banyak ditempatkan pada porsi pasar yang muncul dari definisi pasar yang tidak tepat (Lubis dan Sirait (ed), 2009).

Definisi pasar bersangkutan dari beberapa otoritas pengawas persaingan usaha adalah sebagai berikut: Federal Trade Commission (FTC), Amerika Serikat dalam Department of Justice (DOJ) Merger Guidelines (COMMISSION AUTHORIZED, 1987) mendefinisikan pasar bersangkutan sebagai : "a product or group of products and a geographic area in which it is sold such that a hypothetical, profit-maximizing firm, not subject to price regulation, that was the only present and future seller of those products in that area could impose a "small but significant and non transitory" increase in price above prevailing or likely future levels". Undang-undang No. 5 Tahun 1999 Pasal 1 angka 10 mendefinisikan pasar bersangkutan sebagai: "Pasar bersangkutan adalah pasar yang berkaitan dengan jangkauan atau daerah pemasaran tertentu oleh pelaku usaha atas barang dan atau jasa yang sama atau sejenis atau substitusi dari barang dan atau jasa tersebut" Berdasarkan definisi tersebut, maka dapat disimpulkan bahwa pasar bersangkutan adalah batasan kancah persaingan, baik secara geografis maupun ketersediaan alternatif produk, yang memungkinkan terjadinya proses substitusi antar produk.

\section{1) Pasar Produk}

Faktor yang dipertimbangkan preferensi atau selera konsumen merupakan faktor penentu dalam pendefinisian pasar produk diwakili oleh indikator utama yaitu harga, karakter atau ciri dari produk yang bersangkutan dan kegunaan (fungsi).

\section{2) Pasar Geografis}

Penetapan pasar berdasarkan aspek geografis sangat ditentukan oleh ketersediaan produk yang menjadi obyek analisa yaitu kebijakan perusahaan, biaya transportasi, lamanya perjalanan, tarif dan peraturan-peraturan yang membatasi lalu lintas perdagangan antar kota/wilayah. Berbagai faktor tersebut akan menentukan luas dan cakupan wilayah dari produk yang dijadikan obyek analisa. Dalam hal ini, perdagangan via internet (on line trading) serta mekanisme transaksi paperless cenderung 
mengaburkan hambatan dan batasan antar wilayah.

\section{c. Ekstrateritorialitas}

Ekstrateritorialitas adalah keadaan pengecualian dari yurisdiksi hukum lokal, biasanya sebagai hasil dari negosiasi diplomatik. Poin krusial dari ekstrateritorialitas penegakan hukum persaingan usaha adalah perluasan yurisdiksi sehingga UU No. 5 Tahun 1999 dan segenap peraturan pelaksanaannya, dapat diberlakukan pula bagi pelaku usaha yang berada di negara lain namun tindakannya memiliki dampak anti persaingan terhadap pasar dan kondisi perekonomian di Indonesia.

Ekstrateritorialitas penegakan hukum persaingan usaha ditemukan dalam pengawasan merger di Indonesia. Peraturan KPPU No. 2 Tahun 2013, KPPU hanya berwenang untuk mewajibkan pelaku usaha merger melakukan notifikasi dan memberikan hak konsultasi. KPPU tidak memiliki kewenangan untuk membatalkan kegiatan merger asing yang mengakibatkan praktik monopoli atau persaingan usaha tidak sehat dalam pasar domestik.

\section{Simpulan}

Beranjak dari isu hukum yang merupakan pokok masalah yang kemudian dianalisa melalui pembahasan, maka penelitian ini dapat diambil beberapa kesimpulan sebagai berikut: Pertama, pada Revolusi Industri 4.0 aspek penguasaan teknologi menjadi kunci penentu daya saing, munculnya fenomena sharing economy antar pihak yang berbisnis termasuk inovasi di bidang keuangan Financial Technology (Fintech) sejatinya dapat mendorong ekonomi inklusif. Keberadaan UU No. 5 tahun 1999 tentang Larangan Praktek Monopoli Dan Persaingan Usaha Tidak Sehat yang saat ini berlaku belum dapat memayungi kepentingan pelaku usaha, mitra usaha, pesaing, dan pengguna jasa. Hal ini tampak dari adanya dugaan kartel bunga Fintech $P 2 P$ Lending yang mengakibatkan konsumen kurang memiliki pilihan apabila hendak menggunakan jasa keuangan tersebut.

Simpulan kedua, pembadanan (embodying) prinsip-prinsip, norma, dan aturan hukum Fintech merupakan pengembanan hukum yang signifikan. Sebagai bisnis Revolusi Industri 4.0, hukum Fintech belum memiliki pengaturan yang menerjemahkan prinsip, norma dan aturan yang terkait terutama perihal larangan praktek mononopoli dan persaingan usaha tidak sehat di antaranya pengaturan tentang: definisi pelaku usaha, pasar yang bersangkutan, dan pengaturan tentang ekstrateritorialitas.

Berdasarkan simpulan tersebut, maka penulis menyampaikan saran sebagai berikut: Pertama, sebagai pendorong ekonomi inklusif, Fintech $P 2 P$ Lending harus dimanfaatkan secara maksimal dengan meminimalkan resiko baik bagi pemberi dana, penyelenggara, maupun penerima dana. OJK sebagai Lembaga yang menaungi bisnis model baru ini harus mensosialisasikan hak dan kewajiban pemberi dan penerima dana serta mengawasi penyelenggara secara intensif guna meminimalkan terjadinya Persaingan Usaha Tidak Sehat dalam bisnis ini. Kedua, pembadanan (embodying) prinsip-prinsip, norma, dan aturan hukum Fintech harus segera dibuat dalam bentuk peraturan perundang-undangan mengingat Fintech $P 2 P$ Lending sudah terlaksana sehingga para pihak yang terlibat didalamnya dapat memperoleh kemanfaatan, keadilan dan kepastian hukum.

\section{DAFTAR PUSTAKA}

AFPI. (n.d.). Asosiasi Fintech Pendaaan Bersama Indonesia (AFPI). AFPI. https://www.afpi.or.id/members/page/3

Andersen, W., \& Rogers, C. P. I. (1999). Antitrust Law: Policy and Practice (Casebook Series) 3rd Edition. Lexis 
Nexis Matthew Bender.

Antoni, V. (2019). Penegakan Hukum atas Perkara Kartel di Luar Persekongkolan Tender di Indonesia. Mimbar Hukum Fakultas Hukum Universitas Gadjah Mada, 31(1), 95. https://doi.org/10.22146/jmh.37966

Bank Indonesia. (n.d.). BI 7-day (Reverse) Repo Rate. Bank Indonesia. https://www.bi.go.id/id/moneter/bi7day-

RR/penjelasan/Contents/Default.aspx

Barita, H., \& Sulistiyono, A. (2019). Legalitas Penggunaan Metode Harrington dalam Praktek Kartel (Studi Kasus Praktik Kartel Ban Kendaraan Roda Empat). Jurnal Privat Law, VII(1), 98-103.

Baruchello, G. (2013). The Antitrust Revolution in Europe: Exploring the European Commission's Cartel Policy. By Lee McGowan. The European Legacy, 18(1), 89-92. https://doi.org/10.1080/10848770.2012. 737766

Bhakti, R. T. A. (2015). Analisis Yuridis Dampak Terjadinya Pasar Oligopoli Bagi Persaingan Usaha Maupun Konsumen Di Indonesia. Jurnal Cahaya Keadilan, $3(2), \quad 64$. https://doi.org/10.33884/jck.v3i2.965

CnbcIndonesia. (n.d.). Asosiasi Patok Bunga Fintech Maksimal 0,8\%/Hari, Kartel? Cnbilndonesia.

https://www.cnbcindonesia.com/tech/20 190717102811-37-85511/asosiasipatok-bunga-fintech-maksimal-08-harikartel

Darman. (2019). Financial Technology (FinTech): Karakteristik dan Kualitas Pinjaman pada Peer to Peer Lending di Indonesia. Jurnal Manajemen Teknologi, 18(2), 130-137. https://doi.org/10.12695/jmt.2019.18.2. 4

Economics, D. O. F., \& Edition, S. (2008).
The New Palgrave dictionary of economics. In Choice Reviews Online (Vol. 46, Issue 02). https://doi.org/10.5860/choice.46-0666

Garner, B. A. (2004). Black's Law Dictionary: Eighth Editon. Thomson West USA.

Hovenkamp, H. (2016). Federal antitrust policy: the law of competition and its practice. West Academic.

UU Nomor 5 Tahun 1999 tentang Larangan Praktek Monopoli dan Persaingan Usaha Tidak Sehat, Pub. L. No. 5, 46 (1999).

COMMISSION AUTHORIZED, Pub. L. No. V870026 (1987).

https://www.ftc.gov/policy/advocacy/ad vocacy-filings/1987/08/ftc-staffcomment-us-international-tradecommission-matter

Kontan.co.id. (n.d.). Kasus Vega Data dan Barracuda Fintech, Satgas Investasi beri apresiasi ke polisi. Kontan.Co.Id. https://keuangan.kontan.co.id/news/kas us-vega-data-dan-barracuda-fintechsatgas-investasi-beri-apresiasi-ke-polisi

Koutsoyiannis, A. (n.d.). Modern Microeconomics. Palgrave Macmillan UK. https://doi.org/10.1007/978-1-34915603-0

Liputan6. (n.d.). Kepolisian Tangkap 2 Bos Fintech Ilegal Warga China. Liputan6.Com.

https://www.liputan6.com/bisnis/read/4 142989/kepolisian-tangkap-2-bosfintech-ilegal-warga-china

Nasution, F., \& Winarti, R. (2008). Kartel dan Problematikanya. Majalah Kompetisi.

Nemoto, N., Huang, B., \& Storey, D. J. (2019). Optimal Regulation of P2P Lending for Small and Medium-Sized Enterprises. SSRN Electronic Journal, 912.

https://doi.org/10.2139/ssrn.3313999 
Nuraini, L. (1999). Pengaruh Makroekonomi Terhadap Indeks Saham Pada Jakarta Islamic Index (JII) Dan Indeks Saham Syariah Indonesia (ISSI) Periode 2015-2018 [IAIN Tulungagung]. http://repo.iaintulungagung.ac.id/id/eprint/13671

OJK. (n.d.-a). Direktori Fintech (Peer To Peer Lending) per Januari 2020. OJK. https://www.ojk.go.id/id/kanal/iknb/dat a-dan-statistik/direktori/fintech/Pages/Direktori-Fintech-(Peer-To-PeerLending)-per-Januari-2020.aspx

OJK. (n.d.-b). Profile Satgas. OJK. https://www.ojk.go.id/waspadainvestasi/id/tentang/Pages/ProfilSatgas.aspx

Omarini, E. (2018). Peer-to-Peer Lending : Business Model Analysis and the Platform Dilemma A Framework of Definitions in the Peer-to-Peer Lending Landscape. International Journal of Finance, Economics and Trade ( IJFET ), 2(3), 31-41.

Posner, R. A. (2012). Economic Analysis of Law. Aspen Publishers.

Rawls, J. (2019). A Theory of Justice-Teori Keadilan; Dasar- Dasar Fisafat Politik
Untuk Mewujudkan Kesejahteraan Sosial Dalam Masyarakat. Pustaka Pelajar.

Romdhoni, A. H., Tho'in, M., \& Wahyudi, A. (2012). Sistem Ekonomi Perbankan Berlandaskan Bunga (Analisis Perdebatan Bunga Bank Termasuk Riba Atau Tidak). Jurnal Akuntansi Dan Pajak, 13(01). https://doi.org/10.29040/jap.v13i01.190

Santi, E., Budiharto, B., \& Saptono, H. (2017). Pengawasan Otoritas Jasa Keuangan Terhadap Financial Technology ( Peraturan Otoritas Jasa Keuangan Nomor 77/Pojk.01/2016). 6(3), 1-20.

Shidarta, A. (2018). Meuwissen Tentang Pengembanan Hukum, Ilmu Hukum, Teori hukum, dan Filsafat Hukum (A. Gunarsa (ed.); 5th ed.). Refika Aditama.

Tjandra, A. (2020). Kekosongan Norma Penentuan Bunga Pinjaman Financial Technology Peer To Peer Lending. Jurnal Hukum Bisnis Bonum Commune, 3(1), 90-103. https://doi.org/10.30996/jhbbc.v3i1.307 7 